\title{
SOCIAL PROVISIONS OF MOLDOVAN POLITICAL PARTIES FOR PARLIAMENTARY ELECTIONS IN 2014: PROMISES AND RESULTS
}

\begin{abstract}
Social protection of the population is the key element of social reforms and the main direction of state social policy The aim of this paper is to analyze programs of political parties in Moldavia to find out if the promises of social welfare are fulfill after gaining political power. They proposing solutions for the alleviation of social problems, but when they come to power, they have to cope with the realities characterized by insufficient financial means and therefore the electoral promises are contradictory and are not in line with the achievements.
\end{abstract}

Keywords: Moldavia, political parties, welfare, social problems

Social policy defines the set of public policies aimed at achieving social protection and welfare. According to the Ministry of Health, Labour and Social Protection, the promotion of a well-balanced, inclusive social policy tailored to the conditions of our period remains a continual challenge to the institution's efforts to ensure an adequate level of welfare and social security for all members of society.

Social protection of the population is the key element of social reforms and the main direction of state social policy. The implementation of social policy under the current conditions implies the application of new social protection formulas to disadvantaged social categories, new instruments of intervention in social development policies, social and economic reforms with active involvement of society through information, dialogue and consultations.

Regarding this, the consistent promotion of proactive social policies serves as a guarantor of citizens' rights to social protection and security. This desider- 
ate is even more consistent with the commitments assumed by the signing of the Association Agreement with the European Union on June 27, 2014, in Brussels. Thus, the Republic of Moldova confirmed its choice regarding the social-economic development based on the European model, towards democratization and honouring the commitments assumed towards the European fundamental values.

In this context of ideas, we propose to adjust the programmatic social policy provisions of the political parties that became parliamentary through the elections of November 28, 2014, and the concrete actions realised, derived from the Report on the Implementation of the National Action Plan for the Implementation of the Association Agreement Republic of Moldova - European Union (Planului Național de Acțiuni pentru Implementarea Acordului de Asociere Republica Moldova - Uniunea Europeană Accessed on 01.05.2018).

In the Republic of Moldova, in accordance with the legal provisions in force, the political parties are democratic institutions of the rule of law, promote democratic values and political pluralism, contribute to the formation of public opinion, participate by the advancement and support of candidates in the elections and the constitution of public authorities, stimulate citizens' participation in the elections, participate through their representatives in the lawful exercise of state power, carries out other activities in accordance with the law (Legea privind partidele politice 2008).

We will note that judgments are testified in favour of the formation, organization and action of political parties being considered as the catalysts of society around the ideas of national interest (economic development, promotion of social policies, consolidation of democracy, viable external cooperation), as well as in the detriment attributing to them the cause of the division of society based on doctrinal principles or different visions regarding social organization and development in the context of the realization of social policy provisions, which, however, hardly correspond to the expectations of the citizens.

J. La Palombara and M. Weinern in the paper "Political parties and political development" have grounded the assumption that can be represented by the next idea: a party must have a sustainable organization whose life expectancy is superior to its leaders (La Palombara, Weiner 1969: 16). This assumption provides stability to programmatic provisions, including social policy, because in a democratic system these derive from the party's general position being adjusted to the level of social expectations and less in the individual interest of the leader or a small group of influential political actors. At the same time D. Gusti emphasises the idea that the political party is equivalent to the process of gaining power in order to govern the construction of an ethical and social ideal (Gusti 1996: 11) 
Returning to the idea of the citizens' identification with a party, we note that the authenticity of the situation can be brought about by voter's belonging or identifying with the party that promotes a social policy capable of guiding society towards the achievement of national interests. It should be underlined that in the Republic of Moldova all parties promote the ideas of the correct geostrategic direction of foreign policy, stability, social welfare, economic development and quality in education, but the voters identify themselves with the party that promotes a social policy capable to offer a balanced life and milieu prosperity consistent with their expectations and needs.

We consider that within the territorial limits of the Republic of Moldova the pluriparty elections as a major form of the pluralist democracy generated the emergence of new political processes and phenomena. P. Midrigan describes the phenomenon of elections as the "purgatory" of parties, a context in which their relevance for promoting relevant social policy provisions and their realization through the relevant institutional framework is verified (Midrigan 2005: 134).

Moving directly to the presentation of the political programmatic provisions of political parties that have had access into the Parliament of the Republic of Moldova after the most recent parliamentary elections in 2014 (namely, the Party of Communists of the Republic of Moldova, the Party of Socialists of the Republic of Moldova, the Democratic Party, the Liberal Democratic Party of Moldova, and the Liberal Party), we will carry out an analytical tour of the content of the electoral programs highlighting, above all, the social policy options targeted as primary instruments in the development and improvement of the state's internal situation. The barometer for the evaluation of the measures carried out and the obtained results will constitute the Report on the Implementation of the National Action Plan for the Implementation of the Association Agreement between the Republic of Moldova and the European Union.

The Party of Communists of the Republic of Moldova (PCRM) was formed on October 22, 1993, registered by the Ministry of Justice on April 27, 1994, and re-registered on January 15, 1999. PCRM is a political party with a doctrine of democratic socialism. The Party of Communists of the Republic of Moldova was governing during 2001-2009. After the parliamentary elections in July 2009 PCRM is an opposition party, the parliamentary faction of the Communists being composed of 6 MPs. The PCRM is a member of the Union of Communist Parties and a member of the European Left Party (Partidul Comuniștilor din Republica Moldova. (Accessed on 03.05.2018)).

The primary objective of the party on the social policy strand is to restore social equity and improve the quality of life. In this respect, PCRM has committed itself to promote human development policy by improving the quality of life of citizens of the Republic of Moldova. In the view of the authors of the electoral 
program, the party will make the citizens' life longer and more qualitative. The social domain must become the priority object of the state investments and it is no longer accepted as being made up of the area of public expenditures financed on residual criteria. Some quantitative aspects of social policy objectives can be summarized as follows:

- We will increase, at least five times, the allowances for the birth and care for children;

- We will establish financial mechanisms for state participation according to the progressive principle. The starting point will be the birth grant, which will exceed eight times the subsistence minimum;

- The income of healthcare workers will increase four times than that in the last five years, which will help to halt the exodus of health workers from the system;

- The salary of a young budget specialist will exceed four times the subsistence minimum;

- Teachers who have reached retirement age and continue to work in schools will benefit from full wages and will not be deprived of social and work guarantees;

- Income of the population will increase exceeding at least three times the rate of increase in prices;

- The average monthly salary will exceed at least four times the subsistence minimum;

- The average pension will exceed twice the subsistence minimum;

- Pensions, including those for invalidity, will be indexed twice a year - on April 1 and October 1;

In the conclusions of the electoral program, the Communist Party of the Republic of Moldova commits to making the life of the citizens of the Republic of Moldova longer and qualitative. They recognize that health, education and wellbeing are the treasure of the state. According to their program, teachers and doctors, the military and police, scientists and artists, agrarians, officials and workers will be convinced that their work is prestigious but, above all, well remunerated.

The Democratic Party of Moldova (DPM) was formed on February 8, 1997, under the name of the Social-Political Movement "For a Democratic and Prosperous Moldova", registered by the Ministry of Justice on March 25, 1997, and re-registered on December 25, 1998. DPM is a political party with a social-democratic doctrine. The Democratic Party of Moldova is a parliamentary party that participates in the act of government, represented by 42 deputies in the Parliament and 3 ministers in the Government headed by the Prime Minister of the Republic of Moldova. DPM is an associate member of the European Socialist Party (ESP) and a full member of the Socialist International (Partidul Democrat din Moldova. (Accessed on 03.05.2018)). 
One of the slogans for DP's 2014 parliamentary campaign was "The Democratic Party protects families and women," mentioning in the program documents that when it comes to social protection, the party places first the protection of the Moldovan family. A brief analysis of the electoral platform shows us clearly that the authors did not refer to concrete proposals (promises and/or hopes) on a quantitative scale (we will double, we will increase three times, we will decrease four times etc). This approach would have been effective in making comparisons between the content of programs and electoral platforms and evaluating results after four years of governance, a comparison made possible by the use of data taken from the $\mathrm{Na}$ tional Implementation Plan of the Association Agreement. However, we will elucidate a few provisions with the intention to demonstrate that the focus is shifting from general to particular, from a happy and integral family to a respected woman and to educated children in a favourable environment:

- We will work to increase the economy of Moldova and to provide decent incomes in every home, in every family, for parents, to the benefit of the children;

- We will protect the children by supporting them and their parents. We will focus on everything that means good child-upbringing and safety and protection conditions for them. We will support mothers in upbringing and educating children;

- We will improve the place and role of women in our communities. We recognize the extraordinary merit of women in our family and society and we believe they deserve more respect and more support;

- We will assume the goal of doubling the average pension and doubling the average salary in the next years;

- We will promote the reduction of house tax for the families with at least two minors;

- We will maintain the goal of promoting equality in society in the representation of women and men in public office. Experience shows that something more than legislative initiatives are needed to achieve this goal. There is needed a state policy to motivate women and society to promote and support them.

The conclusions of electoral provisions stem from the platform of the party where the vision focuses on the protection of the Moldovan family by guaranteeing safety and raising the level of living conditions for the citizens of the country's villages and cities.

1. The Liberal Party (LP) was formed on September 5, 1993, under the name of the Reform Party (RP), registered by the Ministry of Justice on September 28 of the same year and re-registered on February 17, 1999. LP is a political party with a liberal doctrine. The party participated in the governing act between 20092013 and 2015-2017. In May 2017 LP is an opposition parliamentary party rep- 
resented by 9 deputies in the Parliament. LP is an observer member of the Alliance of Liberals and Democrats for Europe (ALDE) (Partidul Liberal. (Accessed on 04.05.2018)).

The Party policy on social protection consists of:

- Prioritize mainstreaming of family issues (child education and elderly care as close to family as possible) in local, regional, national development agendas;

- Developing and implementing sustainable policies for demographic recovery, increasing birth rates and life expectancy of the population;

- Effective control of external migration, maintaining the relationship of Moldovan migrants with the family and the Republic of Moldova;

- Ensuring the protection of Moldovan citizens living abroad, including for profit;

- Adjustment of wages, pensions and other financial income to match the actual costs of a family (family with minors, the elderly, pupils and students etc.) including the subsistence minimum;

- Implementing effective policies in the field of child rights protection;

- Development of child protection measures based on the community principle, especially in rural areas;

- Elaboration of immigration policies for the Republic of Moldova;

- Promoting public-private partnerships in the field of social protection;

- Increasing the role of civil society in decision-making and social protection programs;

- Supporting the private system of social protection, including private pension funds;

- Attracting financial support programs and projects from donors in the European Union;

- Developing policies for social inclusion of people with special needs.

The party believes that the only real solution for economic and social solidarity is to increase the welfare of individuals and does not exclude the resource redistribution policy as a means of achieving the objectives of economic and social cohesion. It considers that the most effective form of redistribution is citizens' access to education, modern health care and health insurance systems, and pension insurance systems. Citizens of the Republic of Moldova must benefit from an efficient social security system in which they engage responsibly and use all opportunities by which the state creates an environment conducive to economic development.

2. The Liberal Democratic Party of Moldova (LDPM) was formed on December 8, 2007, and registered by the Ministry of Justice on January 25, 2008. LDPM is a political party with a conservative doctrine. The Liberal Democratic Party of Moldova is an opposition parliamentary party. Its parliamentary faction 
is being composed of 5 deputies. LDPM had governed between September 2009 and October 2015. LDPM is an observer member of the European People's Party (EPP) (Partidul Liberal Democrat din Moldova (Accessed on 04.05.2018)).

By analyzing the Party visions and programmatic provisions, we deduce the idea that the party proposed in 2014 ambitious goals as follows:

- Create in the next ten years, tens of thousands of jobs generated by state investment in national infrastructure projects (road construction, school reconstruction, social objectives);

- To implement a minimum of an important infrastructure project in the next two years in every locality of the Republic of Moldova;

- Improve social protection programs by reducing the dependence of certain categories of citizens on social assistance and by encouraging their employment in a workplace;

- Develop and implement fiscal incentive policies to support the companies investing in training and employing young people and graduates;

- Develop, with the financial support of the European Union, a new national lending and business support program launched by/for women;

- Destroying the monopolies that hinder competition and raise consuming costs by building competitive food distribution centres.

According to the electoral platform of the party, Moldova is undergoing difficult transformations. Too many of our citizens live in difficult conditions being affected by unemployment and low wages. The party's plan aiming at making major changes in the country by 2020 is reflected in more jobs, better living conditions, less corruption and integration into the European Union.

3. The Party of Socialists of the Republic of Moldova (PSRM) was formed on June 29, 1997, registered by the Ministry of Justice on August 6 of the same year and re-registered on February 26, 1999. During the period 2005-2011, the party was named the Patria-Rodina Party of Socialists. PSRM is a political party with the doctrine of democratic socialism and it is an opposition parliamentary party. The parliamentary faction of the Socialists is composed of 24 Members (Partidul Socialistilor din Republica Moldova (Accessed on 05.05.2018)).

Probably the best bidders of electoral promises were the Socialists, who juggled with figures, sums and percentages so far unfound in the text of electoral contestants' programs, either in 2014 or in other electoral years. By it the objectives to be achieved after 2014 have the following financial and value load:

- They will implement a program to support young families - "maternal capital". There will be transferred a deposit account of 15,000 lei for the birth of the first child, 30,000 lei for the second one and 50,000 lei for the third one and more; 
- They will pay a „family salary” to one of the spouses who is responsible for raising and educating three and more children in a volume that is equal to at least the minimum standard of living;

- They will provide young families with state-guaranteed loans for the flat purchase. It is provided the cancellation of $15 \%$ of the loan amount at the birth of the second child and $35 \%$ of it at the birth of the third one;

- They will create the opportunity, starting from 2015, for the successful students to transfer from contract-based studies to funding from the budget. There are increasing scholarships to the minimum subsistence level, as well as increasing number of scholarship recipients;

- They will re-launch the program to support young entrepreneurs - the state will contribute to the creation and development of at least 500 business projects;

- They will provide young specialists with social housing and indemnities at the beginning of their careers. Culture and social security, i.e. „accommodation” indemnities and social housing for young doctors and teachers;

- For the next two years, they will ensure the increase of the minimum guaranteed income of the population to the minimum subsistence level, in the meantime, returning to the system of nominative compensations for several categories of citizens, regular indexing of all cash payments, anticipating the inflation rates, reviewing the state aid granting criteria, simplifying bureaucratic procedures, raising social benefits for disabled children at least 5 times, granting the status of civil servant to doctors and teachers;

- They will equal, until 2017, the minimum guaranteed state income of the population with the minimum living standard;

- They will limit the surcharges for essential products and medicines to $7 \%$ $10 \%$. For more essential products as well as for medicines, the surcharge is from $200 \%$ to $500 \%$, i.e. it exceeds $2-5$ times the cost price of the product;

- They will equal the pensions of the people who started to receive them until 1999 and later this year. Pensions will be indexed at least 20 percent. By 2019, the amount of the pension will twice exceed the minimum living standard.

Based on the party's own views, the socialists advocate the building of a social state, a fair society without which the social-economic renaissance of Moldova is unthinkable.

The evaluation of the electoral provisions devoted to social policy allows their analysis in the light of the taken actions and the obtained results, derived from the National Action Plan for the Implementation of the Association Agreement between the Republic of Moldova and the European Union. In the text of the Plan, we identify the social policy aspects of the idea that the parties strengthen their dialogue and cooperation on promoting the International Labour Organization's Decent Work 
Agenda (ILO), employment policy, health and safety at work, social dialogue, social protection, social inclusion, gender equality, combating discrimination practices and social rights, thus, contributing to the promotion of better jobs, poverty reduction, strengthening cohesion of social development, sustainable development and quality of life. In this context, the proposed concrete actions can be elucidated as follows:

- Signing the Council of Europe Convention on Preventing and Combating Violence Against Women and Domestic Violence;

- Introducing special temporary measures to ensure a fair representation of women and men in decision-making structures;

- Reforming the vocational training system, with a strong focus on the inclusion of people with disabilities and other vulnerable groups;

- Develop a study evaluating the implementation of the National Employment Strategy 2007-2015 and recommendations for developing a new Employment Strategy;

- Development of active measures on the labour market; approving the new law on employment and social protection for jobseekers;

- Developing capacities for labour market analysis, monitoring and forecasting;

- Elaboration and implementation of the annual employment plans;

- Expand cooperation by negotiating and signing agreements on circular / seasonal migration between the Republic of Moldova and the destination countries of the European Union to jointly manage the migration flows, as well as the establishing appropriate national and regional mechanisms;

- Implementation of the Action Plan for the years 2014-2016 regarding the support of the reintegration of the citizens returned from abroad and been approved by the Government Decision no. 339 of May 20, 2014;

- Developing the new Policy Paper on Gender Equality for the period 20162020;

- Initiate negotiations on bilateral social security agreements with the countries of destination of migrant workers: Italy, Greece, Spain, France, Israel and the continuation of negotiations with Turkey, Lithuania, Latvia;

- Making tripartite consultations between the social partners on labour issues and social-economic issues of national interest;

- Continuous improvement of the methodology for calculating the incomes to the social assistance;

- Reviewing the way in which agricultural income is calculated for an objective assessment of the monthly income of the family claiming social assistance;

- Connecting the Automated Information System „Social Assistance” to the database of several organs, which will allow for the correct identification of the socially vulnerable families; 
- Adjusting the characteristics, the score and the threshold for assessing family welfare according to the population living standard.

In order to strengthen the role of territorial social assistance structures in the implementation of social assistance policies and further development of the integrated social services system, by Government Decision no. 828 of November 20, 2015, it was approved the Framework Regulation for the organization and functioning of the local specialized body in the field of social assistance and family protection and of its structure types. At the same time, by Order No. 208 of December 22, 2015, of the Ministry of Labour, Social Protection and Family there were approved the service provision standards for the territorial social assistance structures, and the guides and the methodology for the implementation of the service delivery standards by the territorial social assistance structures. In order to strengthen the network of social workers and to implement an effective training and professional evaluation mechanism, on November 18, 2016, by Government Decision no. 1263 it was approved the Regulation on the Organization and Functioning of the National Social Assistance Agency and its Structure. One of the Agency's core functions is to facilitate the process of strengthening the professional capacities of staff in the social assistance system. The "Social Assistance" Automated Information System (AIS), launched in September 2013, is currently performing the necessary data exchange with the AIS Population State Register (PSR), the National Social Security House and the National Agency for Employment and Border Police. A study to assess the implementation of the National Employment Policy Strategy 2007-2015 and the recommendations for the development of a new Employment Strategy was developed and presented. Also, the National Employment Strategy for 2017-2021 was elaborated and approved by the Government on December 28, 2016. It ensured the introduction of special temporary measures to provide a fair representation of women and men in decision-making structures through Law no. 71 of April 14, 2016, amending and completing certain legislative acts. The document pleads for a minimum share of $40 \%$ for both sexes to be established in the lists of candidates for the parliamentary and local elections, as well as for the formation of the Government.

Concerning the harmonization of national legislation with the acquis communautaire, we highlight the fact that bilateral social security agreements have been initiated and negotiated with the countries of destination of migrant workers. Negotiations have been launched on:

- Agreement on social security between the Republic of Moldova and the Republic of Turkey and the Administrative Arrangement for its implementation (Ankara, June 23-26, and Chisinau, August12-14, 2014);

- Agreement between the Republic of Moldova and the Republic of Latvia on social security (October 8-9, 2014); 
- Agreement between the Republic of Moldova and the Republic of Lithuania in the field of social protection and the Administrative Arrangement for its application (October 1, 2014);

- Moldovan-Italian consultations on social security (November 14, 2014);

- Agreement between the Republic of Moldova and the State of Israel on social security (2014);

- The Administrative Arrangement for the Application of the Agreement on Social Security between the Republic of Moldova and the Kingdom of Belgium (Government Decision No. 258 of May 18, 2015, approved the signing of the Administrative Arrangement);

- Negotiations on the draft Agreement between the Republic of Moldova and the Federal Republic of Germany on social security (2016) were launched.

A detailed analysis of the electoral promises for the period of January 01, 2014 - December 31, 2016, on the growth of social payments, which are so necessary for the population of the Republic of Moldova, highlights the situation that shows that the new social transfers program launched in 2008 in a monetary form called "Social assistance" is the first step in reforming category-based programs that are given to people through the transition to a poor family supporting system. The aim of this program is to ensure a minimum guaranteed monthly income for the disadvantaged families by granting social assistance based on the assessment of the average monthly family income and the need for social assistance.

Over $51 \%$ of the total number of families receiving social assistance during this period had at least one child. The amount of social aid is in close interdependence between the number of family members and the income declared by the family. Thus, during this period, the average amount for families with a child was 598 lei $(\approx 37 €)$, 2 children -954 lei $(\approx 59 €)$, 3 children -1458 lei $(\approx 89 €)$. Due to the social assistance benefit, many families have emerged from the impasse at which they were at one time, the children were able to continue their studies, grow up in the family and be educated by their parents.

According to the Report on Poverty in the Republic of Moldova presented by the Ministry of Economy, the social benefits, for which mechanisms for determining the applicant's eligibility through income testing are applied, have had a significant impact on the reduction of the poverty level. These payments reduced poverty by about 2.3 percentage points. A significant impact on poverty reduction in rural areas should be granted to social aid. Since 2014 , about $80 \%$ of social assistance recipients are from rural areas. Payments through social assistance have reduced the poverty rate in rural areas by 5 percentage points. If these benefits were not available, the poverty rate in the villages would have constituted $23.8 \%$. Unlike other social payments, social aid is relatively one of the most effective in terms of 
targeting money to the most vulnerable sections of the population. Social aid is the most effective social benefit to combat poverty. About $82 \%$ of the allocated money has reached the poorest families. Payments made through social assistance have reduced the country's poverty rate by almost 2 percentage points.

Government institutional structures involved in implementing this social policy approach are the Ministry of Finance, the State Chancellery, the Ministry of Agriculture and Food Industry, the Ministry of Labour, Social Protection and Family.

4. The last report on the implementation during 2017 of the National Action Plan for the Implementation of the Association Agreement between the Republic of Moldova and the European Union, in 2017-2019, has a single provision dedicated to social policy which states that on December 15, 2017, the Moldovan delegation participated at the second meeting of the sub-committee Moldova-European Union, Cluster 6 "Social Policies, Equal Opportunities, Employment and Public Health". As a result of the sub-committee meeting, the European experts issued a series of recommendations for the Republic of Moldova to implement reforms in the areas of reference and commitments under the Association Agreement, reiterating the availability of the European Union for support and technical assistance to take over the best practices. At the same time, the openness to further dialogue and cooperation on the reported areas was reconfirmed (Raport privind realizarea pe parcursul anului 2017 a Planului Național de Acțiuni pentru Implementarea Acordului de Asociere Republica Moldova - Uniunea Europeană 2017-2019 (Accessed on 06.05.2018))

In conclusion we can say that political party programs contain a section devoted to social policies, a compartment that later serves as basis for the electoral platforms, both for parliamentary and local elections. The political parties in the Republic of Moldova cannot afford the luxury of not proposing solutions for the alleviation of social problems, especially in the present condition of mass poverty, exclusion and labour migration.

But when they come to power, they have to cope with the realities characterized by insufficient financial means and therefore the electoral promises are contradictory and are not in line with the achievements. The situation can cause discontent, especially on the part of socially vulnerable layers. But it is not less true that dissatisfaction emerge into the organization and conduct of protest and street actions. For example, during 2015-2017 they were anchored on politico-institutional and social issues.

Thus, ruling parties are able to honour only a part of the promises of a social bill invoking the lack of budgetary means, and the parties in opposition do not have the necessary mechanisms to force the government to promote active social policies ensuring the inclusion of socially vulnerable groups and the development of 
the middle class. In general, the history of nearly 30 years of independence of the Republic of Moldova denotes that good intentions, high expectations and small achievements remain only on paper. In addition, with the exception of the 1994 parliamentary elections, social problems were not the determining factor of victory in the elections for the supreme legislative forum.

\section{Bibliography}

Gusti, D. (1996), Partidul politic. Sociologia unui sistem al partidului politic. In: Doctrinele partidelor politice. București: Garamond.

La Palombara, J., Weiner, M. (1969), Politicalparties and political development. Princeston: Princeston University Press.

Legea privind partidele politice. Nr. 294 din 21.12.2007. Published in MO no. 4244 of 29.02.2008.

Midrigan P. (2005) Partidele politice în procesul electoral (cazul Republicii Moldova) In: MOLDOSCOPIE (Probleme de analiză politică). Part XXX, Chişinău: CEP USM,.

Partidul Comuniștilor din Republica Moldova. http://www.e-democracy.md/elections/ parliamentary/2014/opponents/pcrm/ (Accessed on 03.05.2018).

Partidul Democrat din Moldova. http://www.e-democracy.md/elections/parliamentary /2014/opponents/pdm/ (Accessed on 03.05.2018).

Partidul Liberal Democrat din Moldova. http://www.e-democracy.md/elections/ parliamentary/2014/opponents/pldm/ (Accessed on 04.05.2018).

Partidul Liberal. http://www.e-democracy.md/elections/parliamentary/2014/opponents/pl/. (Accessed on 04.05.2018).

Partidul Socialistilor din Republica Moldova. http://www.e-democracy.md/elections /parliamentary/2014/opponents/psrm/ (Accessed on 05.05.2018).

Planului Național de Acțiuni pentru Implementarea Acordului de Asociere Republica Moldova - Uniunea Europeană. https://monitorizare.gov.md/reports/Raport\%20PNAAA.html (Accessed on 01.05.2018).

Raport privind realizarea pe parcursul anului 2017 a Planului Național de Acțiuni pentru Implementarea Acordului de Asociere Republica Moldova - Uniunea Europeană 2017-2019. http://www.mfa.gov.md/img/docs/Raport-consolidatimplementarea-2017-PNA-AA-2017-2019.pdf (Accessed on 06.05.2018). 


\section{Zabezpieczenia społeczne w programach mołdawskich partii politycznych, w wyborach parlamentarnych w 2014 roku. Wyniki i obietnice}

\section{Streszczenie}

Ochrona socjalna społeczeństwa jest kluczowym elementem reform społecznych i głównym kierunkiem polityki społecznej państwa. Celem tego artykułu jest analiza programów partii politycznych w Mołdawii, aby dowiedzieć się, czy obietnice dotyczące dobrobytu są spełniane po uzyskaniu władzy politycznej. Partie w swoich programach proponują rozwiązania w celu złagodzenia problemów społecznych, ale kiedy dojdą do władzy, muszą radzić sobie z realiami w postaci niewystarczających środków finansowych, a zatem obietnice wyborcze nie są spełniane

Słowa kluczowe: Mołdawia, partie polityczne, dobrobyt, problemy społeczne 